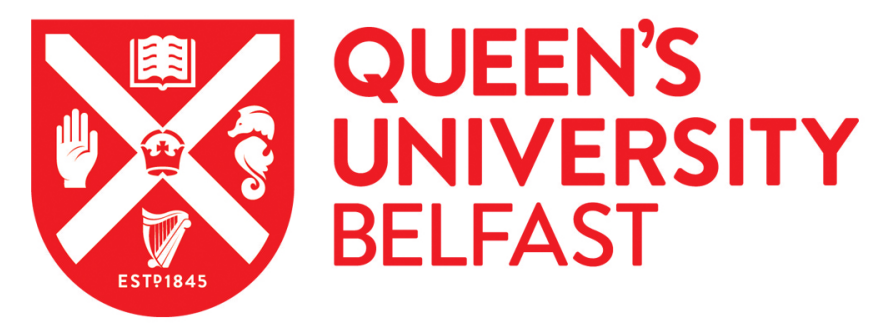

\title{
Neonatal TSH levels in Northern Ireland from 2003 to 2014 as a measure of population iodine status
}

Mullan, K., Patterson, C., Doolan, K., Cundick, J., Hamill, L., McKeeman, G., McMullan, P., Smyth, P., Young, I., \& Woodside, J. V. (2018). Neonatal TSH levels in Northern Ireland from 2003 to 2014 as a measure of population iodine status. Clinical Endocrinology. https://doi.org/10.1111/cen.13849

Published in:

Clinical Endocrinology

Document Version:

Peer reviewed version

Queen's University Belfast - Research Portal:

Link to publication record in Queen's University Belfast Research Portal

Publisher rights

Copyright 2018 Wiley. This work is made available online in accordance with the publisher's policies. Please refer to any applicable terms of use of the publisher.

\section{General rights}

Copyright for the publications made accessible via the Queen's University Belfast Research Portal is retained by the author(s) and / or other copyright owners and it is a condition of accessing these publications that users recognise and abide by the legal requirements associated with these rights.

Take down policy

The Research Portal is Queen's institutional repository that provides access to Queen's research output. Every effort has been made to ensure that content in the Research Portal does not infringe any person's rights, or applicable UK laws. If you discover content in the Research Portal that you believe breaches copyright or violates any law, please contact openaccess@qub.ac.uk. 
Title Page

Short title: Neonatal TSH in Northern Ireland 2003-2014

Title: Neonatal TSH levels in Northern Ireland from 2003 to 2014 as a measure of population iodine status

Dr Karen Mullan ${ }^{1}$, Professor Chris Patterson ${ }^{2}$, Dr Katy Doolan ${ }^{2}$, Dr Jennifer Cundick ${ }^{3}$, Dr Lesley Hamill ${ }^{2}$ Dr Gareth McKeeman ${ }^{3}$, Dr Paul McMullan ${ }^{1}$, Prof Peter Smyth ${ }^{4}$, Prof lan Young ${ }^{2}$, Professor Jayne V. Woodside ${ }^{2}$

${ }^{1}$ Regional Centre for Endocrinology and Diabetes, Royal Victoria Hospital Belfast

${ }^{2}$ Centre for Public Health, School of Medicine, Dentistry and Biomedical Science, Queen's University Belfast

${ }^{3}$ Regional Biochemistry Laboratory, Royal Victoria Hospital Belfast

${ }^{4}$ University College Galway

Corresponding author:

Karen Mullan ${ }^{1}$

karen.mullan@belfasttrust.hscni.net

Key words: iodine, status, neonatal, TSH

Funding:

This article forms part of a research programme commissioned by Safefood, a public body with the role of promoting awareness and knowledge of food issues on the island of Ireland. 


\section{Abstract}

Objective: The re-emergence of iodine deficiency in the UK has recently been reported in a large cohort of teenage girls including from Northern Ireland (NI) using the gold standard spot urinary iodine concentration. We wished to explore and confirm this by analysing neonatal thyroid stimulating hormone (nTSH) levels in the NI population.

Design We analysed the $\mathrm{nTSH}$ heel prick tests results from the NI national screening database between 2003 and 2014. The WHO propose a definition for population iodine sufficiency at $<3 \%$ of the population with $\mathrm{nTSH}$ results $>5 \mathrm{mIU} / \mathrm{L}$.

Methods Anonymised results from 288,491 nTSH tests were retrieved and prevalence rates of results at increasing cutoffs including $>2 \mathrm{mIU} / \mathrm{L}$ and $>5 \mathrm{mlU} / \mathrm{L}$ calculated. We also assessed for possible seasonal variation in nTSH results.

Results An overall population prevalence of $0.49 \%$ with TSH $>5 \mathrm{mIU} / \mathrm{L}$ was found, indicating population iodine sufficiency with no year attaining a prevalence $>3 \%$. The prevalence of nTSH $>2 \mathrm{mIU} / \mathrm{L}$ decreased to $4.1 \%$ in 2007 and subsequently increased to $9.8 \%$ in 2014. Modest seasonal variation was also detected, with higher levels among April/May births.

Conclusions The neonatal TSH database suggests iodine sufficiency in the NI population. However, the rising frequency of results $>2 \mathrm{mIU} / \mathrm{L}$ may indicate an emerging mild iodine deficiency. This is one of the largest and longest studies of its kind in the UK and the first carried out in NI. The summer months may be a time of increased risk for iodine deficiency in our pregnant women whose requirements are increased and who are not currently targeted by any iodine fortification programme in the UK. 


\section{Introduction}

lodine is an essential trace element required for production of thyroid hormones, and an adequate supply of dietary iodine is of particular importance during pregnancy due to the increased demands on the maternal thyroid to compensate for foetal requirements ${ }^{1}$. Severe iodine deficiency during development results in cretinism and growth retardation ${ }^{2}$. At the mild end of the spectrum observational studies have shown associations between both mild maternal iodine deficiency and decreased child cognition ${ }^{3}$. Within the United Kingdom (UK) and Ireland, for many years, iodine intakes were thought to be adequate. More recently, a survey in 2011 reported iodine levels in over 700 teenage girls living across the $\mathrm{UK}^{4}$. Results suggested that this group were mildly iodine deficient, with a median urinary iodine concentration (UIC) of $80 \mu \mathrm{g} / \mathrm{L}$ (deficiency $<100 \mu \mathrm{g} / \mathrm{L}$ ). Published data from the Republic of Ireland (ROI) also indicated mild deficiency in the general population in the 1990s and, more recently, in pregnant women ${ }^{5,7,8}$.

lodine is found in a range of foods, with the richest sources being fish and dairy products. Within Ireland and the UK, milk and dairy products tend to be the main sources of dietary iodine, ${ }^{9,10}$. The amount of iodine in foods varies according to the iodine content of the soil, time of year (with iodine content of products such as milk being higher in winter as compared to summer months) and farming techniques (use of iodine containing cattle feed and cleaning agents). The UK and ROI have no formal iodine fortification programme in place, so that iodine status depends entirely on dietary intake. This contrasts with many European countries which have a programme of salt iodization in place ${ }^{5}$.

Population iodine status may be assessed in a number of ways although the gold standard remains population median spot urinary iodine concentration ${ }^{6}$. Other methods include prevalence of goitre, and blood thyroglobulin concentrations. The World Health Organisation (WHO) has further proposed that neonatal thyroid stimulating hormone (TSH) levels may also be used to assess the iodine sufficiency in populations and to investigate the effect of iodination programmes ${ }^{5}$.

Screening programmes for $\mathrm{nTSH}$ are predominately to detect and monitor congenital hypothyroidism where $\mathrm{nTSH} \geq 20 \mathrm{mIU} / \mathrm{L}$ is considered diagnostic and a $\mathrm{nTSH} \geq 10 \mathrm{mlU} / \mathrm{L}$ warrants repeat sampling. Screening for neonatal hypothyroidism was started in the UK between 1979 and $1981^{11}$. Neonatal TSH is considered to be a sensitive marker of iodine status because of the relatively low iodine content of the neonatal thyroid and high turnover. In the presence of iodine deficiency, iodine turnover within the neonatal thyroid is further heightened, resulting in hyper stimulation of $\mathrm{TSH}^{12}$. The WHO suggests that, within a population, a prevalence of $<3 \%$ of $\mathrm{nTSH}$ values above $5 \mathrm{mIU} / \mathrm{L}$ may be used to indicate iodine sufficiency ${ }^{5}$. It has also been suggested that, rather than absolute cut-offs, nTSH trends over time may be a more suitable method of monitoring iodine status in mildly deficient populations ${ }^{13,14}$. Such a trend was identified in a study of nTSH in ROI births between $1995-2006^{13}$. In this study, according to the WHO cut-off, the Irish mothers were considered iodine sufficient during that time. However a year on year upward trend of TSH $>2 \mathrm{mIU} / \mathrm{L}$ was observed. The authors pointed to the potential for the population to become iodine deficient and advocated continued monitoring of blood spot neonatal TSH levels into the future. 
Studies have been undertaken in Belgium, Wales and Australia, with considerable variation observed in neonatal TSH levels $13,15,16$. In the majority of these studies, when applying the WHO recommended cutoff, authors concluded that the frequency of TSH concentrations above $5 \mathrm{mIU} / \mathrm{L}$ was unexpectedly low, considering that within those countries there were numerous reports of mild iodine deficiency, either in the general population or among cohorts of pregnant women. Therefore this cut-off is felt by some to be insensitive when considering iodine levels in mildly deficient populations. This study aimed to explore trends in nTSH levels in the Northern Irish population between 2003 and 2014. 


\section{Subjects and Methods}

\section{NI TSH neonatal screening}

As part of the national neonatal screening programme, all babies born in $\mathrm{NI}$ have a bloodspot nTSH measurement taken from a heel prick sample provided on day 5-8 after birth ${ }^{11}$. For the purpose of this investigation, anonymised access was obtained of $\mathrm{nTSH}$ results from samples collected between January 2000 and August 2014.

As this research was limited to the anonymous, secondary use of information, previously collected in the course of normal care, the researchers sought and were granted ethical approval by the NHS Research Ethics committee (reference: 14/SC/1331) and governance approval from the Belfast Health and Social Care Trust (reference: 14113IY-AS).

Within the Northern Ireland Regional Endocrine Laboratory, blood TSH has been measured by dissociation-enhanced fluoroimmunoassay (DELFIA) on an autoDELFIA analyser since 2000 (Perkin Elmer Life \& Analytical Sciences, Bucks, UK: www.perkinelmer.co.uk/lab-solutions). Although data were available from 2000, there was a considerable spike in nTSH levels in 2002. It is thought that this may relate to a change from using wet to dry plates and a change in the paper used with the autoDELFIA around this time. It was felt that data collected before this change in methodology might not be comparable and so was excluded.

\section{Statistical Methods}

Time series methods were employed to investigate the long-term trends and seasonality in the monthly nTSH results during the period from January 2003 to August 2014. Results were categorised using cut-points of $>2,5,10$ and $20 \mathrm{mIU} / \mathrm{L}$ for consistency with previous publications ${ }^{14,15}$. Analysis of the long term trends in the proportions of results exceeding these cut-points was first conducted using the Joinpoint regression program (Version 4.2 - June 2015; Statistical Methodology and Applications Branch and Data Modelling Branch, Surveillance Research Program National Cancer Institute, Bethesda, MD, USA) which was developed for surveillance of trends in incidence rates ${ }^{17}$.

Having established the long-term trends, residuals were calculated and submitted to a multiple regression analysis incorporating cosine and sine terms to represent months of the year. The cosine and sine values were assigned in accordance with angles when months were arranged on the circumference of a circle (January $=15^{\circ}$, February $=45^{\circ}, \ldots$, December $=345^{\circ}$ ). Robust standard error estimates were used in the multiple regression (Stata release 12, College Station, Texas) to attenuate possible exaggerated significance caused by autocorrelation in the time series. The amplitude of the seasonal component was estimated as $\sqrt{ }\left[b_{\sin }{ }^{2}+b_{\cos ^{2}}{ }^{2}\right]$, and the peak angle as $\tan ^{-1}\left(b_{\sin } / b_{\cos }\right)$ with the quadrant determined by the signs of the regression coefficients, $b_{\sin }$ and $b_{\cos }{ }^{18}$. 


\section{Results}

After removal of a small number of repeat results, a total of 288,491 TSH results for $\mathrm{NI}$ for the 140 month period were received for analysis. Results were categorised using cut-points of $>2,5,10$ and $20 \mathrm{mIU} / \mathrm{L}$ and aggregated according to month of sampling. The average number of samples per month was 2061 (range 1622-2329).

Between the years of $2003-2014,6.2 \%$ and $0.49 \%$ of neonates had blood TSH concentrations $>2 \mathrm{mIU} / \mathrm{L}$ and $>5 \mathrm{mIU} / \mathrm{L}$, respectively (Table 1 ). In no year over the collection period did the proportion of TSH concentrations $>5 \mathrm{mIU} / \mathrm{L}$ rise above $3 \%$.

Joinpoint analysis of the monthly results showed no long term trends for TSH $>5 \mathrm{mIU} / \mathrm{L}$ but that the prevalence of TSH $>2 \mathrm{mIU} / \mathrm{L}$ decreased to a minimum of $4.1 \%$ for the year 2007 and increased to $9.8 \%$ for the year 2014 (Figure 1). This represents an annual percentage increase of $0.6 \%$ ( $95 \% \mathrm{Cl} 0.4-$ $0.8)(\mathrm{p}<0.0001)$.

The seasonality for results $>2 \mathrm{mIU} / \mathrm{L}$ and $>5 \mathrm{mIU} / \mathrm{L}$ conformed closely to a sinusoidal (sine wave) pattern (Figure 2). The fitted peak was in early-May with the percentage for $>5 \mathrm{mIU} / \mathrm{L}$ varying about the $0.49 \%$ average by $\pm 0.09 \%$ (i.e. from $0.40 \%$ to $0.58 \%$ ). The $>2 \mathrm{mIU} / \mathrm{L}$ analysis showed a peak in mid-April with an amplitude of $\pm 0.7 \%$ about the $6.2 \%$ average.

Results for $\mathrm{nTSH}$ frequency $>10$ and $>20 \mathrm{mIU} / \mathrm{L}$ were $0.13 \%$ and $0.06 \%$ respectively. There was no evidence of seasonality with either the $>10 \mathrm{mIU} / \mathrm{L}$ or the $>20 \mathrm{mIU} / \mathrm{L}$ cut-points.

Use of robust variance estimates in the multiple regression to mitigate the effects of autocorrelation did not materially alter the findings. 


\section{Discussion}

Based on the WHO proposal of iodine sufficiency the population of $\mathrm{NI}$ are considered iodine sufficient between 2003 and 2014, with a neonatal population prevalence of TSH values $>5 \mathrm{mIU} / \mathrm{L}$ at $0.5 \%$. The WHO first recommended the cut off of $3 \% \mathrm{nTSH}>5 \mathrm{mIU} / \mathrm{L}$ in its 1994 guideline but this was removed from the 2001 guideline amid a lack of consensus regarding the potential impacts of sampling, antiseptic use and collection papers used. It was re-inserted in its 2007 guideline citing the study by Zimmerman et al in which the frequency of $\mathrm{nTSH}>5 \mathrm{mU} / \mathrm{L}$ (measured at 3-4 days) decreased from $2.9 \%$ to $1.7 \%$ after the institution of an iodized salt program in Switzerland ${ }^{19}$.

It has been suggested that the cut off of $3 \%$ frequency of $\mathrm{nTSH}>5 \mathrm{mIU} / \mathrm{L}$ is not sensitive enough to detect mild iodine deficiency. This is because several studies have observed median urinary iodine concentration, which is still regarded as the gold standard, within the mildly deficient range which was not accompanied by a $\geq 3 \%$ frequency of $n T S H>5 \mathrm{mIU} / \mathrm{L}$ among the same populations (Table 2 ).

Although there is no matched maternal urinary iodine data in NI that corresponds with the years 2003-2014 we can point to three local cohorts with urinary iodine sampling performed around these time frames. Firstly, the NI subset of the UK schoolgirl cohort from 2009 was found to be mildly iodine deficient ${ }^{4}$. We have also reported recently, in abstract form, low median urinary iodine levels in a cohort of NI pregnant women from 2014-2015 which was found throughout all trimesters and into the post-partum period ${ }^{20}$. However, we have also reported in abstract form a further cohort of schoolgirls surveyed from NI in 2014-2015 as part of a larger survey in the whole of Ireland which was found to be iodine sufficient albeit at the lower end of the normal range ${ }^{21}$. We have found significant difficulties in sampling schoolgirls using the gold standard method of median spot urinary iodine concentration because of reticence about participation among this age group. This means that sampling biases are likely to explain some of the varying results from these studies. Overall we consider these cohorts in $\mathrm{NI}$ to fit into a pattern of borderline sufficiency and at times mild iodine deficiency.

A lower cut-off of $>2 \mathrm{mIU} / \mathrm{L}$ for assessing population iodine status has been suggested by some authors. Our frequency at a cut-off of $>2 \mathrm{mIU} / \mathrm{L}$ was $6.2 \%$ compared to the Welsh cohort of 10.9 $11.9 \%$ and the Belgian cohort at a frequency of $21-40 \%{ }^{13,15}$ ( see Table 2). Each of these geographical areas has been previously documented to have mild iodine deficiency.

It has been suggested that trends in blood spot TSH within the normal range should also be examined for changing iodine status among populations. The percentage of TSH values at the lower cut off $>2 \mathrm{mIU} / \mathrm{L}$ in our study showed an increase from 2007 onwards. An increasing trend $>2 \mathrm{mIU} / \mathrm{L}$ was also observed in babies born in ROI between 1995-2006 ${ }^{14}$. The authors suggest that this coincided with reports of a decline in maternal urinary iodine in ROI thus supporting an association. Peters et al reported that the frequency of $\mathrm{nTSH}>4 \mathrm{mU} / \mathrm{L}$ in London increased from 2006 to 2012 but there is no data in this study for frequency $>2 \mathrm{mU} / \mathrm{L}^{22}$.

Our frequency of blood spot $\mathrm{nTSH}>5 \mathrm{mIU} / \mathrm{L}(0.49 \%)$ is substantially lower than the published ROI cohort (2.4-3.6\%) in babies born between 1995-2006, the Welsh cohort (1.5\%) between 2011-2013, the Belgian cohort (2.6-3.3\%) between 2009-2011 and the Australian cohort (2.2\%) in 2004 (Table 2). Potential explanations for these differences include the timing of sampling and also differing TSH 
methodologies but the variation could also be due to potential differences in geographical and nutritional factors between the cohorts ${ }^{13-16}$.

The timing of blood sample collection is likely to impact on nTSH results. Lott et al. have described the decline in blood spot TSH in American newborns over the first days of life with the $97.5^{\text {th }}$ centile TSH dropping from $17 \mathrm{mIU} / \mathrm{L}$ at $2-3$ days to $12 \mathrm{mIU} / \mathrm{L}$ at $\geq 4$ days ${ }^{23}$. Guidance on when samples are collected differs depending on National Screening Programme Centre standards ${ }^{11}$. The Belgian cohort had TSH collected three to five days after birth which may, in large part, explain their higher levels while the Welsh cohort collected at five to eight days which was like the NI cohort. The Welsh authors used the same methodology and assay as the current study and they noted a difference between day 4 and day 5 measurements ( $1.5 \%$ vs $0.99 \%$ with $\mathrm{nTSH}>5 \mathrm{mU} / \mathrm{L}$ ). We do not have a breakdown of samples per day in this study. Sampling was encouraged, and usually happened, on or around day 5 .

Blood spot sampling quality may impact on nTSH results. Samples in this study were processed from one centre (Regional Endocrine Laboratory, Belfast) which was subject to the UK External Quality Scheme with satisfactory reports across this period. Sample acceptance criteria did not change during this period and so sample quality would not have varied significantly. However, within the Belgian cohort, various methods were employed to measure nTSH levels over a three year period. Some methodological bias may have remained despite the authors' attempts at standardisation resulting in a higher percentage of raised nTSH values.

Geographical variation of iodine content of locally available water, milk, eggs and fish are possible contributing factors to $\mathrm{nTSH}$ variations. Further factors surrounding the pregnancy and birth of neonates may also impact on nTSH values, but robust data are not always available for scrutiny. For example birth weight and the use of iodine containing antiseptics have been associated with variations in $\mathrm{nTSH}$ values ${ }^{13,24,25}$.

Ethnicity affecting nTSH is now recognised with higher levels seen in Pakistani, Bangladeshi and Chinese populations. Although we do not have a breakdown of results according to ethnicity the $\mathrm{NI}$ census data demonstrates very low levels of ethnic diversity over time $(99.3 \%$ and $98.3 \%$ coded as white in 2001 and 2011 respectively) ${ }^{22}$.

Our study demonstrated a modest seasonality in nTSH, with levels rising within the normal range during spring/summer months of March to August indicating lower maternal iodine stores as compared to September to February. Seasonality of cases of congenital hypothyroidism have been described in some but not all cohorts ${ }^{25-27}$. Seasonality of $\mathrm{nTSH}$ results in the upper end of the normal range rather than seasonality of cases of confirmed congenital hypothyroidism may be a more sensitive marker of iodine deficiency for a population at the lower end of iodine supply. Our results were similar to the ROI and Belgian but not the Welsh cohort ${ }^{13-15}$. Our results mirror the findings among a large cohort of UK schoolgirls demonstrating seasonal variation in median urinary iodine concentration with lowest levels in the summer months ${ }^{4}$. The mechanism of this could in part be due to the previously reported seasonal variations in dairy produce (the principal source of dietary iodine in UK and Irish diets) with lower levels of iodine found in foods in summer months when content of fodder changes ${ }^{10}$. The peaks in nTSH in the current study were seen in late spring as opposed to the summer months so this was slightly unexpected. A further mechanism may involve 
seasonal vitamin D metabolism affecting the hypothalamic-pituitary-thyroid axis with recent studies indicating an inverse relationship between vitamin D levels and TSH ${ }^{28,29}$.

This article is the first publication of its kind from Northern Ireland and one of the largest cohorts in the UK. Results suggest no severe iodine deficiency in this population using over $280,000 \mathrm{nTSH}$ samples. Given the controversy with WHO recommendations we feel the data is useful to the current debate on population monitoring for iodine deficiency. Ongoing surveillance with this method has the advantage of being inexpensive but frequency of values $>5 \mathrm{mIU} / \mathrm{L}$ is not likely to be a good marker of mild iodine deficiency. The value of trends at lower cut off levels of nTSH remains to be seen but shows some promise in identifying populations at risk of mild iodine deficiency. For example significant rises in frequency of $\mathrm{nTSH}>2 \mathrm{mU} / \mathrm{L}$ might be considered a trigger to re-evaluate the population with urinary iodine concentrations. Seasonal variation in neonatal TSH has also been demonstrated and may reflect a population at the borderline of iodine sufficiency and therefore vulnerable to seasonal environmental and husbandry shifts. As our population is currently unprotected by any iodine fortification programme these results again raise the need for iodine nutritional guidance for pregnant women in whom iodine requirements are increased. 
Declaration of Interest: We declare no conflict of interest that could be perceived as prejudicing the impartiality of the research reported.

Funding: This article forms part of a research programme commissioned by Safefood, a public body with the role of promoting awareness and knowledge of food issues on the island of Ireland: Project Reference No: 01-2013 


\section{References}

1. Zimmermann MB. Iodine deficiency. Endocr Rev. 2009;30:376-408

2. Pearce EN, Lazarus JH, Moreno-Reyes R, Zimmermann MB. Consequences of iodine deficiency and excess in pregnant women: an overview of current knowns and unknowns. Am J Clin Nutr. 2016;104 Suppl 3:918S-23S

3. Bath SC, Steer CD, Golding J, Emmett P \& Rayman MP. Effect of inadequate iodine status in UK pregnant women on cognitive outcomes in their children: results from the Avon Longitudinal Study of Parents and Children (ALSPAC). Lancet 2013 382:331-337

4. Vanderpump MP, Lazarus JH, Smyth PP, Laurberg P et al; on behalf of the British Thyroid Association UK lodine Survey Group. lodine status of UK schoolgirls: a cross-sectional survey. Lancet 2011 377: 2007-2012

5. Andersson M, De Benoist B, Darnton-Hill I \& Delange F. lodine deficiency in Europe: a continuing public health problem. World Health Organization, Geneva 2007

6. World Health Organization. Urinary iodine concentrations for determining iodine status deficiency in populations. Vitamin and Mineral Nutrition Information System. Geneva: 2013

7. Lazarus JH \& Smyth PP. lodine deficiency in the UK and Ireland. Lancet 2008 372:888

8. Nawoor Z, Burns R, Smith DF, Sheehan S, O'Herlihy C \& Smyth PP. lodine intake in pregnancy in Ireland-a cause for concern? Ir J Med Sci 2006 175:21-24

9. Food Standards Agency (2008) Retail survey of iodine status in UK produced dairy foods. FSIS02/08.http://tna.europarchive.org/20140306205048/http://www.food.gov.uk/science/research Lsurveillance/fsisbranch2008/fsis0208

10. Bath SC, Button S \& Rayman MP. lodine concentration of organic and conventional milk: implications for iodine intake. Br J Nutr 2012 107:935-40

11. A laboratory guide to newborn screening in the UK for congenital hypothyroidism (2014). https://www.bsped.org.uk/clinical/docs/CHTLabGuideFebruary2014.pdf

12. Delange F. Screening for congenital hypothyroidism used as an indicator of the degree of iodine deficiency and its control. Thyroid 1998 8:1185-1192

13. Vandevijvere S, Coucke W, Vanderpas J et al. Neonatal thyroid stimulating hormone concentrations in Belgium: A useful indicator for detecting mild iodine deficiency? PLoS One 2012 7(10) e477770

14. Burns R, Mayne PD, O'Herlihy C et al. Can neonatal TSH screening reflect trends in population iodine intake? Thyroid 2008 18: 883-888

15. Evans C, Nix AB, Hillier S \& Moat SJ. Neonatal blood TSH concentration in Wales (UK): an indicator of iodine sufficiency. Clin Endocrinol 2014 81: 606-609 
16. Travers CA, Guttikonda K, Norton CA, Lewis PR, Mollart L, Wiley V, Wilcken B, Eastman CJ, Boyages SC. lodine status in pregnant women and their newborns: are our babies at risk of iodine deficiency? Med J Aust. 2006;184(12):617-20.

17. Kim HJ, Fay MP, Feuer EJ \& Midthune DN. Permutation tests for joinpoint regression with applications to cancer rates. Stat Med 2000 19:335-351

18. Stolwijk AM, Straatman $\mathrm{H}$, Zielhuis GA. Studying seasonality by using sine and cosine functions in regression analysis.J Epidemiol Community Health. 1999 Apr;53(4):235-8

19. Zimmermann MB, Aeberli I,Torresani T, Burgi H. Increasing the iodine concentration in the Swiss iodized saltprogram markedly improved iodine status in pregnant women and children: a 5-y prospective national study. Am J Clin Nutr.2005;82:388-92

20. McMullan P, Hamill L, McCance D, Woodside J Mullan K. lodine nutritional status among pregnant women and their offspring in Northern Ireland (NI). Presented at Society for Endocrinology BES, Brighton, UK Endocrine Abstracts 201644 OC6.4

21. Mullan K, Hamill L, Doolan K, Young I, Smyth P, Flynn A, Patterson C, Walton J, Meharg A, Woodside J and 4I group: Bell M, Black N, Graham U, McCance D, McHugh C, McKeever E, McMullan $P$, McQuaid S,O'Loughlin A , Tuthill A. lodine status on the Island of Ireland. Irish Endocrine Society Conference Abstract 2016.

22. Peters C, Brooke I, Heales S, Ifederu A, Langham S, Hindmarsh P, Cole TJ. Defining the Newborn Blood Spot Screening Reference Interval for TSH: Impact of Ethnicity. J Clin Endocrinol Metab. 2016;101(9):3445-9

23. Lott JA, Sardovia-lyer M, Speakman KS et al. Age dependent cutoff values in screening newborns for Hypothyroidism. Clinical Biochemistry 2004 37: 791-797

24. McElduff A, McElduff $P$, Wiley $\vee \&$ Wilcken $B$. Neonatal thyrotropin as measured in a congenital hypothyroidism screening programme: influence of mode of delivery. J Clin Endocrinol Metab 2005 90 h6361-6363

25. Korada M, Pearce MS, Avis E, Turner S, Cheetham T. TSH levels in relation to gestation, birth weight and sex. Horm Res. 2009;72(2):120-3.

26. Pearce MS, Korada M, Day J, Turner S, Allison D, Kibirige M, Cheetham TD. Increasing incidence, but lack of seasonality, of elevated TSH levels, on newborn screening, in the North of England. J Thyroid Res. 2010:;101948

27. Hall SK, Hutchesson AC, Kirk JM. Congenital hypothyroidism, seasonality and consanguinity in the West Midlands, England. Acta Paediatr. 1999:;88(2):212-5.

28. Das G, Taylor PN, Javaid H, Tennant BP, Geen J, Aldridge A, Okosieme O.Seasonal variation of vit $D$ and serum thyrotropin levels and its relationship in a euthyroid caucasian population. Endocr Pract. 2018;24(1):53-59 
29.Barchetta I, Baroni MG, Leonetti F, De Bernardinis M, Bertoccini L, Fontana M, Mazzei E, Fraioli A, Cavallo MG. TSH levels are associated with vitamin $D$ status and seasonality in an adult population of euthyroid adults. Clin Exp Med. 2015 Aug;15(3):389-96

30. Vandevijvere S, Mourri AB, Amsalkhir S, Avni F, Van Oyen H, Moreno-Reyes R. Fortification of bread with iodized salt corrected iodine deficiency in school-aged children, but not in their mothers: a national cross-sectional survey in Belgium. Thyroid. 2012;22(10):1046-53

31. Vandevijvere S, Amsalkhir S, Mourri AB, Van Oyen H, Moreno-Reyes R. lodine deficiency among Belgian pregnant women not fully corrected by iodine-containing multivitamins: a national crosssectional survey. Br J Nutr. 2013 Jun 28;109(12):2276-84.

32. Bath SC, Combet E, Scully P, Zimmermann MB, Hampshire-Jones KH, Rayman MP. A multi-centre pilot study of iodine status in UK schoolchildren, aged 8-10 years. Eur J Nutr. 2016;55(6):2001-9. 
Table 1 Percentage of Northern Ireland neonatal blood TSH values $>2 \mathrm{mIU} / \mathrm{L},>5 \mathrm{mIU} / \mathrm{L},>10 \mathrm{mIU} / \mathrm{L}$ and $>20 \mathrm{mIU} / \mathrm{L}$ in 2003-2014

\begin{tabular}{|c|c|c|c|c|c|c|c|c|c|}
\hline \multirow[t]{2}{*}{ Year } & \multirow{2}{*}{$\begin{array}{c}\text { Results } \\
\mathrm{N}\end{array}$} & \multicolumn{2}{|c|}{$>2 \mathrm{mIU} / \mathrm{L}$} & \multicolumn{2}{|c|}{$>5 \mathrm{mIU} / \mathrm{L}$} & \multicolumn{2}{|c|}{$>10 \mathrm{mIU} / \mathrm{L}$} & \multicolumn{2}{|c|}{$>20 \mathrm{mIU} / \mathrm{L}$} \\
\hline & & $\mathrm{n}$ & $\%$ & $\mathrm{n}$ & $\%$ & $\mathrm{n}$ & $\%$ & $\mathrm{n}$ & $\%$ \\
\hline 2003 & 21,935 & 1,384 & $6.3 \%$ & 96 & $0.44 \%$ & 26 & $0.12 \%$ & 7 & $0.03 \%$ \\
\hline 2004 & 23,031 & 1,549 & $6.7 \%$ & 136 & $0.59 \%$ & 33 & $0.14 \%$ & 11 & $0.05 \%$ \\
\hline 2005 & 23,072 & 1,356 & $5.9 \%$ & 119 & $0.52 \%$ & 31 & $0.13 \%$ & 17 & $0.07 \%$ \\
\hline 2006 & 24,477 & 1,299 & $5.3 \%$ & 118 & $0.48 \%$ & 23 & $0.09 \%$ & 6 & $0.02 \%$ \\
\hline 2007 & 25,211 & 1,031 & $4.1 \%$ & 92 & $0.36 \%$ & 26 & $0.10 \%$ & 14 & $0.06 \%$ \\
\hline 2008 & 26,139 & 1,257 & $4.8 \%$ & 96 & $0.37 \%$ & 31 & $0.12 \%$ & 14 & $0.05 \%$ \\
\hline 2009 & 25,759 & 1,444 & $5.6 \%$ & 148 & $0.57 \%$ & 52 & $0.20 \%$ & 29 & $0.11 \%$ \\
\hline 2010 & 26,447 & 1,766 & $6.7 \%$ & 136 & $0.51 \%$ & 37 & $0.14 \%$ & 20 & $0.08 \%$ \\
\hline 2011 & 26,260 & 1,761 & $6.7 \%$ & 104 & $0.40 \%$ & 17 & $0.06 \%$ & 8 & $0.03 \%$ \\
\hline 2012 & 25,756 & 1,784 & $6.9 \%$ & 134 & $0.52 \%$ & 38 & $0.15 \%$ & 17 & $0.07 \%$ \\
\hline 2013 & 24,287 & 1,650 & $6.8 \%$ & 121 & $0.50 \%$ & 29 & $0.12 \%$ & 14 & $0.06 \%$ \\
\hline $2014 \#$ & 16,117 & 1,580 & $9.8 \%$ & 107 & $0.66 \%$ & 26 & $0.16 \%$ & 16 & $0.10 \%$ \\
\hline Total & 288,491 & 17,861 & $6.2 \%$ & 1,407 & $0.49 \%$ & 369 & $0.13 \%$ & 173 & $0.06 \%$ \\
\hline
\end{tabular}

\# To August 2014 
Table 2: Comparison of neonatal TSH screening programme studies and contemporaneous population surveys of urinary iodine concentration

\begin{tabular}{|c|c|c|c|c|c|c|c|c|c|}
\hline Location & Years & $\begin{array}{r}\text { No. } \\
\text { neonates }\end{array}$ & $\begin{array}{l}\text { Timing } \\
\text { (days) }\end{array}$ & Seasonality & $\begin{array}{c}\mathrm{TSH} \\
>5 \mathrm{mU} / \mathrm{L}\end{array}$ & $\begin{array}{c}\mathrm{TSH} \\
>2 \mathrm{mU} / \mathrm{L}\end{array}$ & \multicolumn{3}{|c|}{$\begin{array}{l}\text { Contemporaneous population surveys of } \\
\text { UIC in region }\end{array}$} \\
\hline & & & & & & & Year & Cohort & $\begin{array}{l}\text { Deficiency } \\
\text { reported }\end{array}$ \\
\hline Australia $^{16}$ & 2004 & 824 & $2-3$ & no & 2.2 & $n / a$ & 2004 & pregnant women $^{16}$ & $\checkmark$ \\
\hline $\begin{array}{l}\text { Rep of } \\
\text { Ireland }{ }^{14}\end{array}$ & $\begin{array}{l}1995- \\
2006\end{array}$ & 73,019 & $5-8$ & yes & $2.4-3.6$ & $\begin{array}{l}19.5- \\
29.3\end{array}$ & 2004-05 & $\begin{array}{l}\text { pregnant/ non- } \\
\text { pregnant women }^{8}\end{array}$ & $\checkmark$ \\
\hline Belgium $^{13}$ & $\begin{array}{l}2009- \\
2011\end{array}$ & 377,713 & $3-5$ & yes & $2.6-3.3$ & $\begin{array}{l}21.0- \\
40.6\end{array}$ & $\begin{array}{l}2010-11 \\
2010-11\end{array}$ & $\begin{array}{l}\text { primary } \\
\text { schoolchildren }^{30} \\
\text { pregnant /non- } \\
\text { pregnant women } \\
\end{array}$ & $\begin{array}{l}x \\
\checkmark\end{array}$ \\
\hline $\begin{array}{l}\text { N Thames } \\
\text { England }^{22}\end{array}$ & $\begin{array}{l}2006- \\
2012\end{array}$ & 824,588 & $5-10$ & $\begin{array}{c}\text { not } \\
\text { explored }\end{array}$ & 0.5 & $n / a$ & 2009 & London teenage girls ${ }^{4}$ & $\checkmark$ \\
\hline Wales $^{15}$ & $\begin{array}{l}2011- \\
2013\end{array}$ & 104,992 & $5-8$ & no & 0.9 & $\begin{array}{l}10.9- \\
11.9\end{array}$ & 2009 & Cardiff teenage girls ${ }^{4}$ & $\checkmark$ \\
\hline $\begin{array}{l}\text { N Ireland } \\
\text { (current) }\end{array}$ & $\begin{array}{l}2003- \\
2014\end{array}$ & 288,491 & $5-8$ & yes & 0.5 & $4.1-9.8$ & $\begin{array}{l}2009 \\
2012-13 \\
2014-15 \\
2014-15\end{array}$ & $\begin{array}{l}\text { teenage girls } \\
\text { primary } \\
\text { schoolchildren }^{32} \\
\text { pregnant women }{ }^{20} \\
\text { teenage girls }\end{array}$ & $\begin{array}{c}\checkmark \\
x \\
\checkmark \\
\text { x-borderline } \\
\text { normal }\end{array}$ \\
\hline
\end{tabular}

UIC: Urinary lodine concentration

n/a - not avaialble 


\section{Figure 1}

Northern Ireland TSH monthly time series data for percentage $>5 \mathrm{mIU} / \mathrm{L}$ (Figure 1a) and $>2 \mathrm{mIU} / \mathrm{L}$ (Figure 1b) with super-imposed long-term trend by Joinpoint (orange) and fitted seasonal pattern ( green)

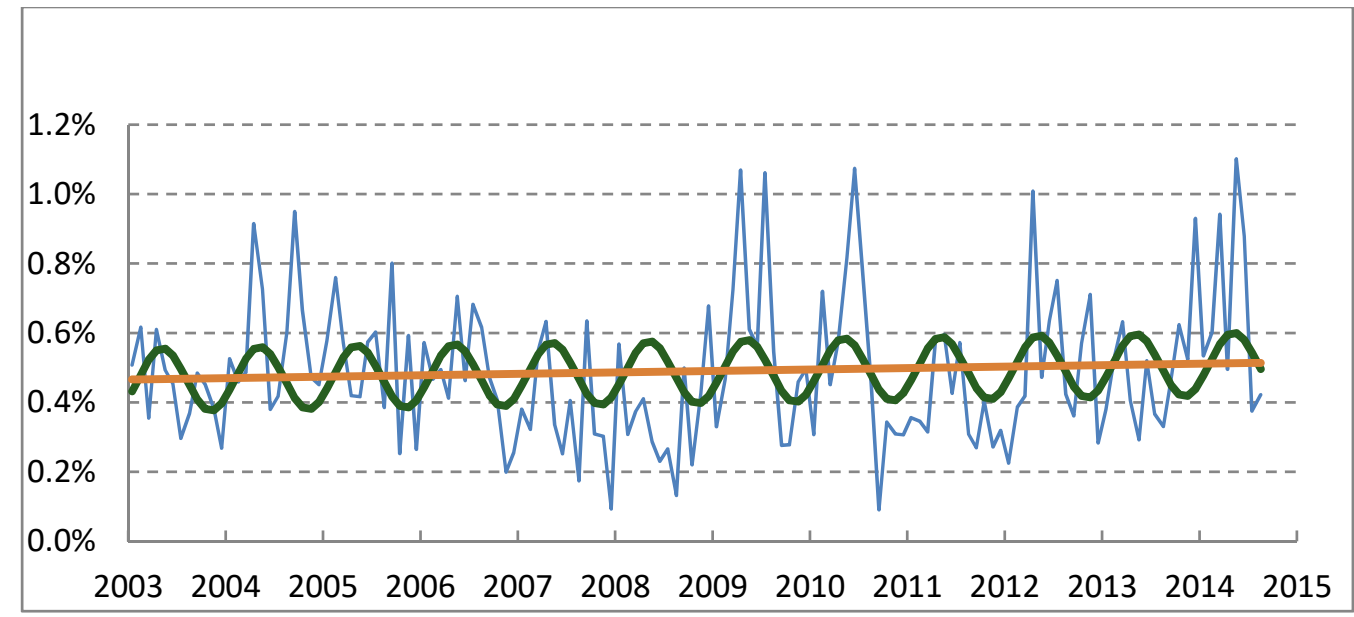

\section{Figure 1a}

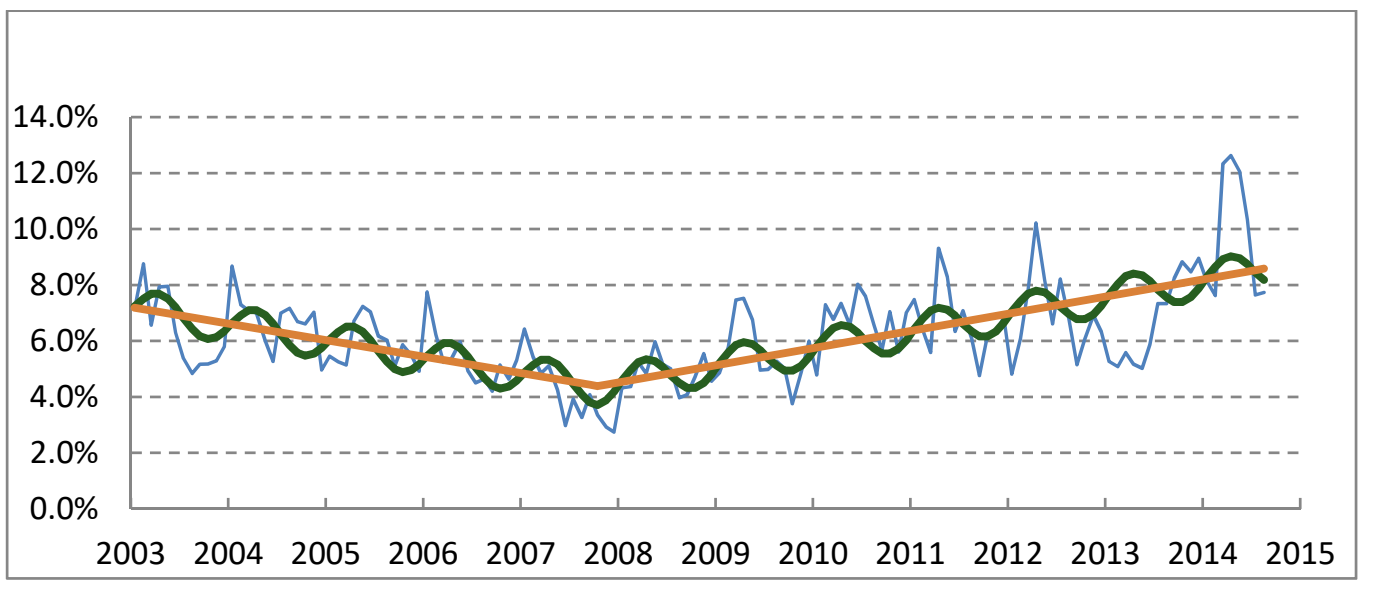

Figure 1b 


\section{Figure 2}

Plot of percentage of children with $\mathrm{nTSH}>5 \mathrm{mIU} / \mathrm{L}$ (Figure 2a) and $\mathrm{nTSH}>2 \mathrm{mIU} / \mathrm{L}$ (Figure $2 \mathrm{~b}$ ) by month in 2003-2014. Error bars show 95\% confidence limits. Fitted seasonal trend (dash)

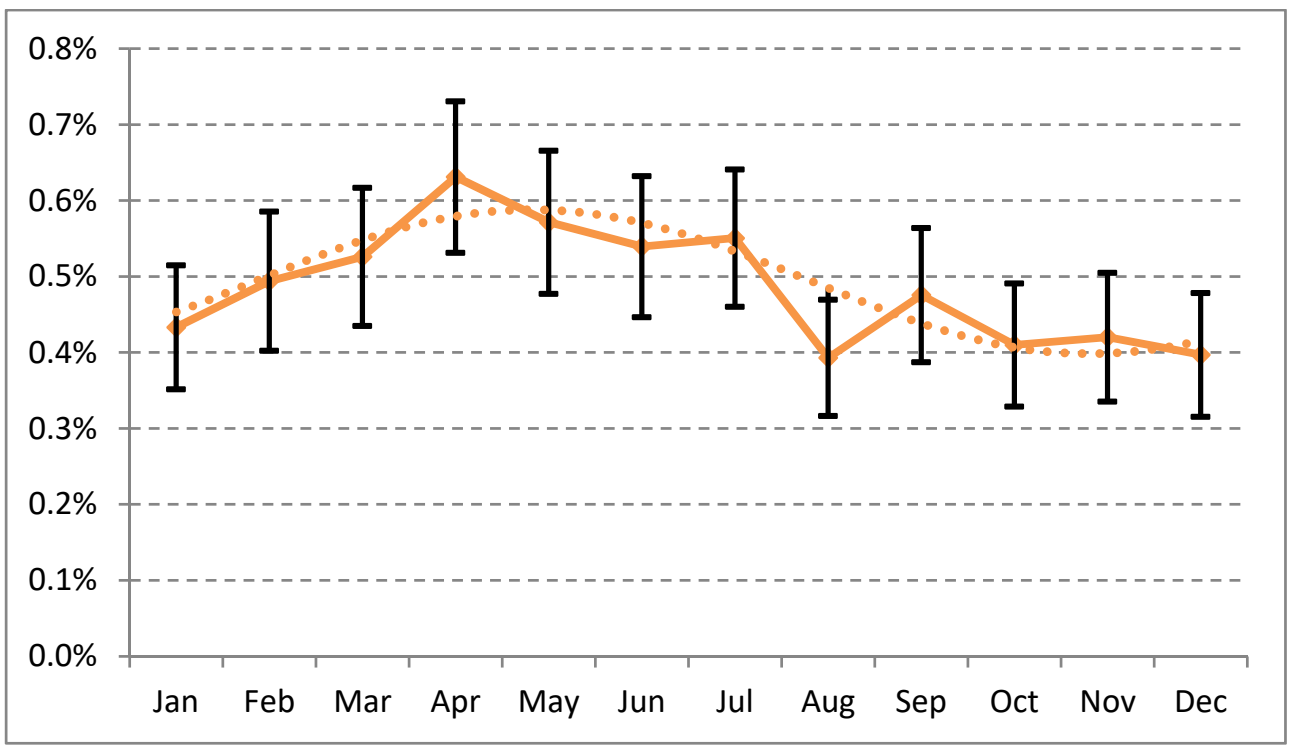

Figure 2a

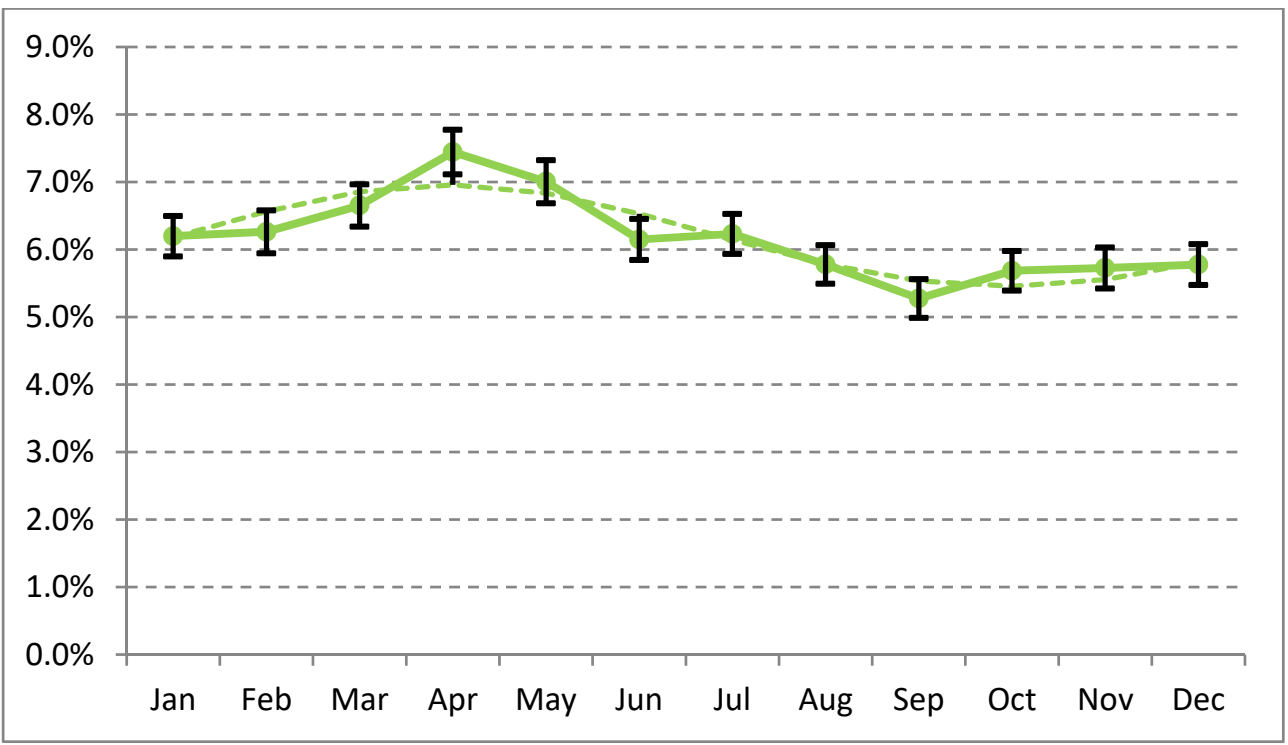

Figure 2b 
